\title{
An Empirical Study on IPO Underpricing of the Shanghai A Share Market
}

\author{
Xiaoyan Wang ${ }^{1, \text { a * }}$ \\ ${ }^{1}$ Room \#604, Y1 Apartment, Shanghai University, 99 Shangda Road, Shanghai 200444, China. \\ a845151049@qq.com
}

Keywords: IPO Underpricing; The Shanghai A Shares; Regression Analysis

\begin{abstract}
The China stock was born for more than 20 years. And the IPO underpricing has become a common phenomenon in securities market. Combined with the current academic research results of IPO underpricing theory, researchers can know that the sentiment of investors, the manipulation of institutions and the introduction of stock index futures can explain IPO underpricing phenomenon from a certain angle. In this paper, by the statistical data of SSE A share IPO and the build of the multiple linear regression model, exploring the factors which cause of the IPO underpricing. The main influence factors that can be summed up are the first day exchange rate, the issuance price earnings ratio etc. Finally, according to the results of relevant research, researchers will raise some useful advice to improve the order of trading market .
\end{abstract}

\section{Introduction}

For the first time an IPO (initial public offerings (IPO): refers to a business or company (Co., Ltd.), it shares to the public sale for the first time (initial public offering, referring to the issue of shares of the company for the first time to the public offering). The securities market in the United States first began to study the issue of IPO underpricing in the first 70 years of twentieth Century. Subsequently, the IPO underpricing has gradually become a common problem in the securities market. Because of the phenomenon of IPO underpricing, investors can get over payment for the subscription of new shares. This will appear even though the two markets are extremely sluggish, and IPO issue can successfully complete the weird phenomenon. This is a shock for the two markets, but also the effectiveness of the IPO pricing has been questioned by the public, the healthy development of China's securities market has caused a serious adverse impact. Therefore, researchers should further explore the factors that explain the IPO underpricing.

\section{The theory explanation survey of IPO underpricing}

Foreign lite rature. Foreign scholars have done some research on the problem of IPO underpricing:

The "winner's Curse" hypothesis

"Winner's Curse" theory (winner's curse hypothesis), also referred to the information as ymmetry hypothesis, assumes that the earliest by rock (1986) is proposed. The hypothesis is based on the asymmetric information theory, because the information asymmetry exists, the investors in the market are divided into informed investors and non-informed investors. Informed investors can judge the new shares more investment value according to his favorable news, while the non insiders clearly cannot do. This will dispel the enthusiasm of the non informed investors to subscribe for new shares, 
the impact of IPO. Therefore, the distribution firm usually uses the underpricing way issue stock, in order to attract more investors.

Speculative bubble hypothesis:

Hypothesis Speculative-bubble (speculation bubble hypothesis), the issue price of the IPO is not undervalued. Because of the convergence of people, the phenomenon of IPO is weak in the long term. The first day of the IPO price will be repeatedly pushed higher, resulting in its much higher than the intrinsic value of the formation of excess returns.

Investment bank credibility assumption:

Hypothesis Underwriter (Reputation) is proposed by Manaster and Cater (1990), which is the main link between the degree of stock IPO Underpricing and the credit of underwriter. The high degree of credit has a smaller risk, so for investors, with the risk signal, will tend to choose the lower risk investment bank. So, investment banks can reduce the degree of IPO underpricing, instead of the subsequent financing process to obtain the corresponding underwriting proceeds.

Domestic literature. Chinese scholars Shu Guang Xiao Shun Cai Jiang(2006) used transaction cost theory to dynamic study of the effect of the system and its changes on China's IPO underpricing.[1]Duan Xiaoming, Liu Yushan(2006) the paper pointed out how to reduce the IPO underpricing rate under current conditions. [2] Zhan Yu Wu, Cheng Hao Wang, Ji Chang Dong (2009) showed that the IPO initial return rate was still at a high level and the inquiry process lack of information disclosure was the main reason for the effective implementation of the impact of the inquiry system. [3] Xue min Zhuang (2009) showed that the issuing scale, profit rate, success rate, and exchange rate, prior to the issuance of asset profit rate.[4] Xie Jin Lou (2010) thought that the classic literature on IPO underpricing of the "winner's Curse" hypothesis could not explain China's A-share IPO underpricing phenomenon.[5] Gao Feng Zou and Zhang Weiying, Xu Xiaowan (2012) thought that the IPO issue price of existence and mature capital market lied in the institutional characteristics during this period China's IPO pricing methods.[6]

\section{Empirical analysis}

Model design. Sample selection:

In this paper, the phenomenon of IPO underpricing in the Shanghai A-share market of China on 2014 and the causes of the phenomenon studied by using multiple regression model. That includes Hainan mining (601969), Anbang pharmaceutical (603998), Fuda shares (603166), science dawn (603019), electric motor (603988) etc. sample selection for the year 2014 in a share market listed 32 shares.

Dependent variable:

The inhibition of IPO is often measured by the excess return of IPO, and its expression is:

$\mathrm{ERi}=(\mathrm{Pit}-\mathrm{Pio}) / \mathrm{Pio}$

ERi is the underpricing of the i stock on the day of the listing; Pit is the closing price of the $\mathrm{i}$ stock on the day of the listing; Pio is the issue price of the i stock only.

Independent variable:

1. The first day turnover rate (Turnover Rate on the first day,TR) : refers to the day of the trading volume and stock IPO issuance of stock turnover ratio. The turnover rate is calculated as follows:

Listed on the first day of the first day of trading volume / turnover rate $=$ number of shares (2) 
2. The issue of earnings (PE): the proportion of the share price and the share of the share earnings per share. Whether stocks are overvalued or undervalued by different prices.

3. The success rate (LOT): refers to the need by random in the purchase of all funds allotment of shares, to guarantee the purchase of fairness. The calculation formula of success rate:

Success rate $=$ the number of shares issued stock / purchase of shares of $* 100 \%$ (3)

4. The time interval (T): issued to the first day of the IPO, the time interval number of days apart from the IPO of the IPO.

5. The amount of funds raised (FUND) :it is equal to the product of the number of shares issued and the issue price.

Proposed hypothesis:

According to the above 5 possible IPO underpricing factors, researchers make the following assumptions :

Hypothesis H1: the first day turnover rate (TR) rate of A was positively correlated with the stock market IPO underpricing

Hypothesis H2: the issue of earnings ratio (PE) and A stock market IPO underpricing negative correlation.

Hypothesis H3: success rate (LOT) was negatively correlated with rate of A stock market IPO underpricing.

Hypothesis H4: the time interval (T) of IPO to IPO is positively related to the IPO underpricing of A shares.

Hypothesis H5: the amount of funds raised (FUND) and IPO shares market A underpricing was negatively related.

Descriptive statistics. In this paper, researchers use the EViews6.0 statistical software to find the results of the IPO underpricing of stock market in 2014 A share.

Table 1 Descriptive Statistics of Cross-sectional Data

\begin{tabular}{c|c|c|c|c|c}
\hline Variable & TR & T & PE & LOT & FUND \\
\hline Mean & 0.273438 & 11.50000 & 20.40656 & 0.729063 & 57858.25 \\
\hline Median & 0.230000 & 11.00000 & 21.68000 & 0.625000 & 41380.55 \\
\hline Maximum value & 0.840000 & 20.00000 & 23.20000 & 1.800000 & 193016.8 \\
\hline Minimum value & 0.090000 & 7.000000 & 12.54000 & 0.280000 & 16800.00 \\
\hline SD & 0.177993 & 3.222902 & 2.952194 & 0.394489 & 44816.39 \\
\hline Skewness & 1.807023 & 0.925173 & -1.459032 & 1.330727 & 1.605872 \\
\hline Kurtosis & 6.084319 & 3.361290 & 4.169567 & 4.022077 & 4.799829 \\
\hline
\end{tabular}

Table 1 is a group of data sets of data for the 2014 Shanghai Stock A shares of the shares of the 32 shares of the shares. From the data in the chart researchers can see, overall turnover rate is high, the average is 0.27 , and the maximum value is 0.84 . This shows that the first day of the IPO, investors vigorously pursued new shares, and therefore caused a lot of trading volume.

Fig. 1: Issue price earnings trend chart (Left)

Fig. 2: IPO exchange rate trends (Right) 

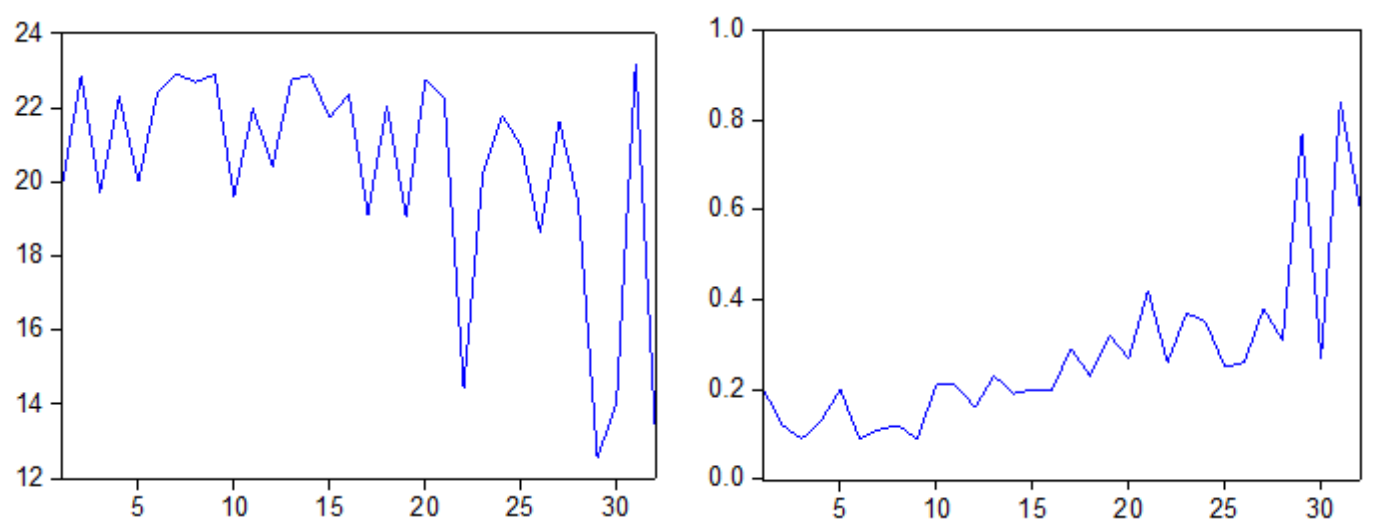

Multiple regression analysis. According to the assumption of the previous hypothesis, researchers will have an effect on the factors of the first day of the underpricing, and establish a multiple linear regression model as follows:

$\mathrm{ER}=\beta 0+\beta 1 \mathrm{TR}+\beta 2 \mathrm{PE}+\beta 3 \mathrm{LOT}+\beta 4 \mathrm{~T}+\beta$ 5FUND $+\varepsilon \mathrm{i}$

According to the results of the above table, the regression party is:

$\mathrm{ER}=-0.443+0.02 \mathrm{~T}-4.0009 \mathrm{LOT}+1.0027 \mathrm{TR}-7.8845 \mathrm{FUND}+\varepsilon$

And $R 2=0.623063$, the results is statistically significant.

\section{Research conclusions}

Through the empirical analysis researchers can see that turnover rate (TR) and A-share market IPO underpricing on the first day are positively correlated with the rate; success rate (lot) with the A-share market IPO underpricing rate was negatively correlated; issuance of new shares to listed on the first day of the time interval (T) and the A-share market IPO underpricing rate was positively correlated; the amount of funds raised (Fund) and the A-share market IPO underpricing rate was negatively correlated. However, the issue of earnings ratio (PE) and A shares market IPO underpricing rate is not particularly significant correlation.

\section{References}

[1]Xiao Shuguang, Jiang Shuncai, institutional factors of the high IPO underpricing of A shares in China [J]. Accounting research, 2006:69-75.

[2]Liu Yushan, Duan Xiaoming, IPO Underpricing and its influence factors in A of China [J]. Journal of Harbin University of Science and Technology, 2006:56-59.

[3]Wang Chenghao, Wu Zhanyu, Dong Jichang. The phenomenon and cause of the SME board IPO underpricing phenomenon and reason empirical research $[\mathrm{J}]$. Harbin University of Science and Technology, 2009:100-108.

[4]Zhuang Xuemin, the cause of the IPO underpricing of small and medium board in China [J]. Economic and management research, 2009:57-69.

[5]Xie Jin Lou, the study on the IPO underpricing of A shares under the background of full circulation [J]. Finance and economy, 2010:70-73. 
[6]Zou Gaofeng, Zhang Wei, Xu Xiaowan, the Constitution and the influencing factors of IPO underpricing in China [J]. Management science journal, 2012:12-30.

[7]Deng Linfang. Empirical research on the impact of IPO underpricing on GEM [D]. China Southwestern University of Finance and Economics, 2013:1-73.

[8]Rock,K.Why New Issues are Underpriced[J]. Journal of Financial Economics, 1986( 15) : 187 212.

[9]Tinic, S. Anatomy of Initial Public Offerings of Common Stock[J].The Journal of Finance,1988( 4). 